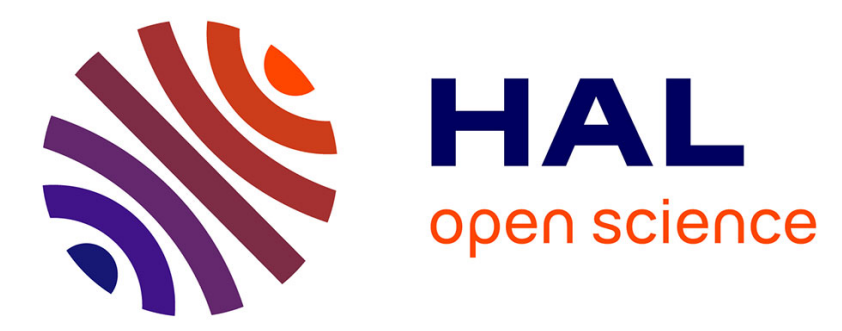

\title{
Density as a factor limiting the workability of $\mathrm{P} / \mathrm{M}$ materials
}

\author{
W. Libura, J. Zasadzinski
}

\section{To cite this version:}

W. Libura, J. Zasadzinski. Density as a factor limiting the workability of P/M materials. Journal de

Physique IV Proceedings, 1993, 03 (C7), pp.C7-721-C7-725. 10.1051/jp4:19937113 . jpa-00251731

\section{HAL Id: jpa-00251731 \\ https://hal.science/jpa-00251731}

Submitted on 1 Jan 1993

HAL is a multi-disciplinary open access archive for the deposit and dissemination of scientific research documents, whether they are published or not. The documents may come from teaching and research institutions in France or abroad, or from public or private research centers.
L'archive ouverte pluridisciplinaire HAL, est destinée au dépôt et à la diffusion de documents scientifiques de niveau recherche, publiés ou non, émanant des établissements d'enseignement et de recherche français ou étrangers, des laboratoires publics ou privés. 


\title{
Density as a factor limiting the workability of $\mathrm{P} / \mathrm{M}$ materials
}

\author{
W. LIBURA and J. ZASADZINSKI
}

University of Mining and Metallurgy, Dept. of Metal Forming and Physical Metallurgy of Non-Ferrous Metals, Al. Mickiewicza 30, 30-059 Kraków, Poland

\begin{abstract}
In this study a general scheme expressing the factors which affect a workability of powder materials is presented. It was found from laboratory experiments that workability of powder metal materials is limited by their density. Aluminium based materials with additions of $\mathrm{Cu}, \mathrm{Ni}$ and $\mathrm{Sn}$ were used in the experiments. Workability determined in compression tests depends strongly on a sintered density, independently of the chemical composition of material. A linear dependence between workability and sintered density was found. The results are related to relatively high density values, taken from the range of $0.85-0.96$ of theoretical density.
\end{abstract}

\section{INTRODUCTION}

In recent years, a wide variety of parts are fabricated by plastic forming of sintered preforms, prepared on the basis of powder metallurgy. Forming of powder metallurgy parts is limited by so-called workability (deformability). Workability of powder sinters or ability to shape changes without failure is not recognized fully as yet. Many years experience in workability testing of as cast metals and alloys allowed the authors to propose the scheme expressing the principal factors affecting the workability of powder sinters [1].

Porosity is a characteristic feature of powder sinters assigned to forming processes. In case of such materials the additional aim of the forming process is to obtain possibly fully dense material. In the work [1] the workability of powder sinters was investigated for the materials prepared on the basis of $\mathrm{Al}$ powder with additions of $\mathrm{Cu}, \mathrm{Ni}$ and $\mathrm{Sn}$. The workability was determined in compression, rolling and extrusion tests. The essential conclusion there was that a dependence exists between workability and porosity (density) of sintered powder metals. This becomes the basis for submitting the thesis that density is a principal factor influencing the workability of powder sinters.

\section{DENSITY AND WORKABILITY OF A1-BASED POWDER SINTERS}

2. 1. Samples preparation technique.

The following powder mixtures were prepared for workability testing (in 


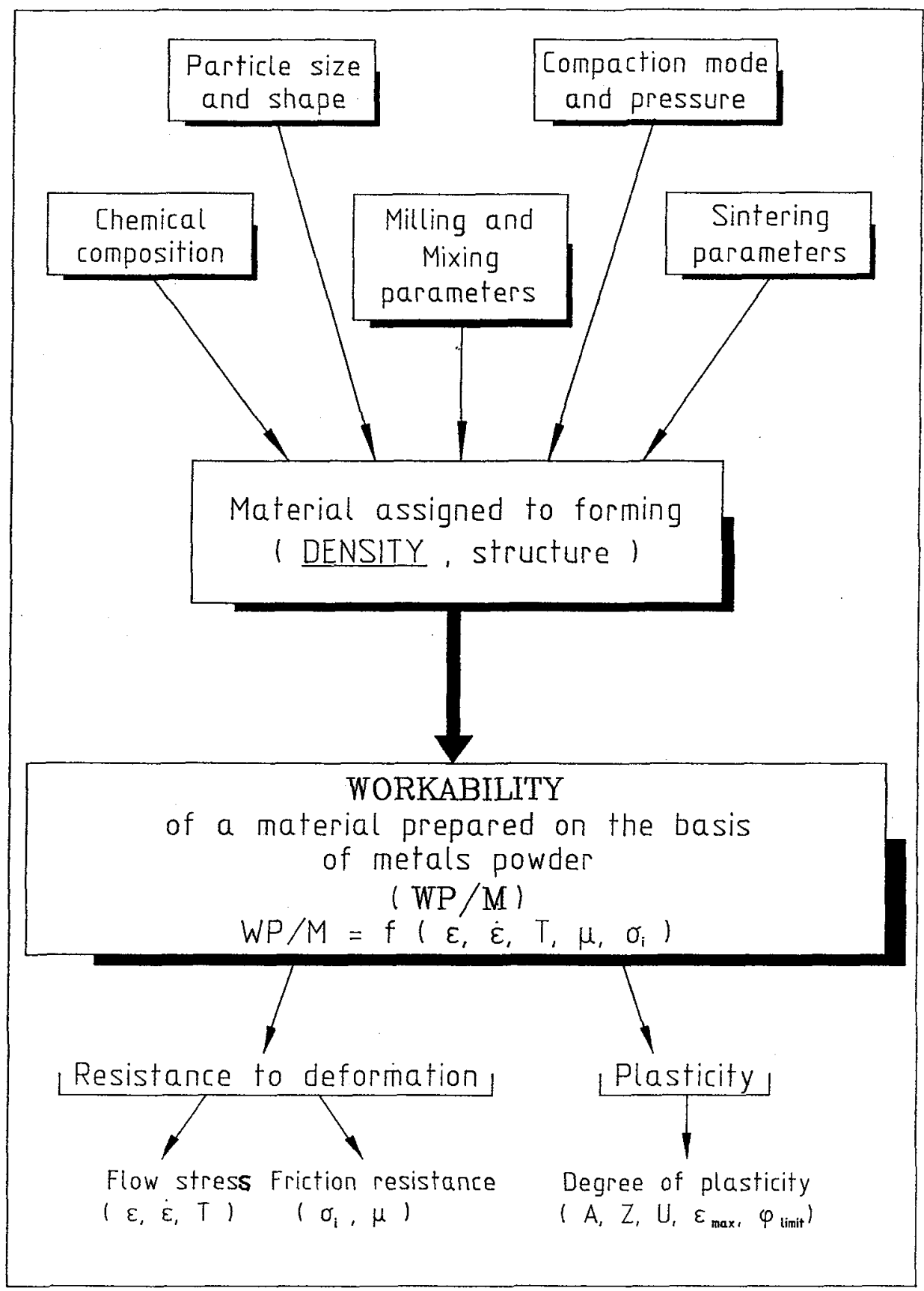

Fig. 1. Factors affecting the workability of $P / M$ materials. 
weight): Al, AlNi10, AlCu5Ni5, AlCu10 and AlSn10. Elemental powders of $150 \mu \mathrm{m}$ $\mathrm{Al}, 63 \mu \mathrm{m} \mathrm{Cu}, 63 \mu \mathrm{m} \mathrm{Ni}, 63 \mu \mathrm{m}$ Sn were mixed with $1.2 \%$ zinc stearate for $30 \mathrm{~min}$., compacted under the pressure of $300 \mathrm{MPa}$ and sintered in vacuum furnace at 773 , 823 and $853 \mathrm{~K}$. The samples of $20 \mathrm{~mm}$ in diameter and $12 \mathrm{~mm}$ in height were subjected to density determination. The results are shown in table 1.

Table 1. Materials density as a function of sintering temperature.

\begin{tabular}{|c|c|c|}
\hline Material & $\begin{array}{c}\text { Sintering } \\
\text { temperature, } \mathrm{K}\end{array}$ & $\begin{array}{c}\text { Density, } \rho^{3} \\
10^{3} \mathrm{~kg} / \mathrm{m}^{3}\end{array}$ \\
\hline \multirow{3}{*}{ Al } & 773 & 2.54 \\
& 823 & 2.55 \\
& 853 & 2.55 \\
\hline \multirow{3}{*}{ AlNi10 } & 773 & 2.47 \\
& 823 & 2.75 \\
& 853 & 2.80 \\
\hline AlCu5Ni5 & 773 & 2.47 \\
& 823 & 2.62 \\
& 853 & 2.76 \\
\hline AlCu10 & 773 & 2.47 \\
& 823 & 2.55 \\
& 853 & 2.72 \\
\hline AlSn10 & 773 & 2.51 \\
& 823 & 2.55 \\
\hline
\end{tabular}

\section{2 Workability testing.}

The compression test is very useful to study the workability of material assigned to various processes. It consists in compression of a sample having cylindrical shape, usually till the moment of sample failure. As a result of friction between the sample and the tool the effect of barrelling can usually be observed. On the lateral, unloaded surface of the sample there occur tensile stresses resulting in material cracking. The reduction value at the moment of cracking is assumed to be a workability measure and may be of use for the elaborating forging, rolling or extrusion processes.

The critical reduction $\varepsilon_{c}$ in compression test is calculated from the dependence:

$$
\varepsilon_{c}=\frac{h_{0}-h_{1}}{h_{0}}
$$

where: $h_{0^{-}}$initial height of sample,

$h_{1}$ - height of sample at the moment of cracking.

The results of the $\varepsilon_{c}$ determination for the materials being tested are shown in Figures 2 and 3. 


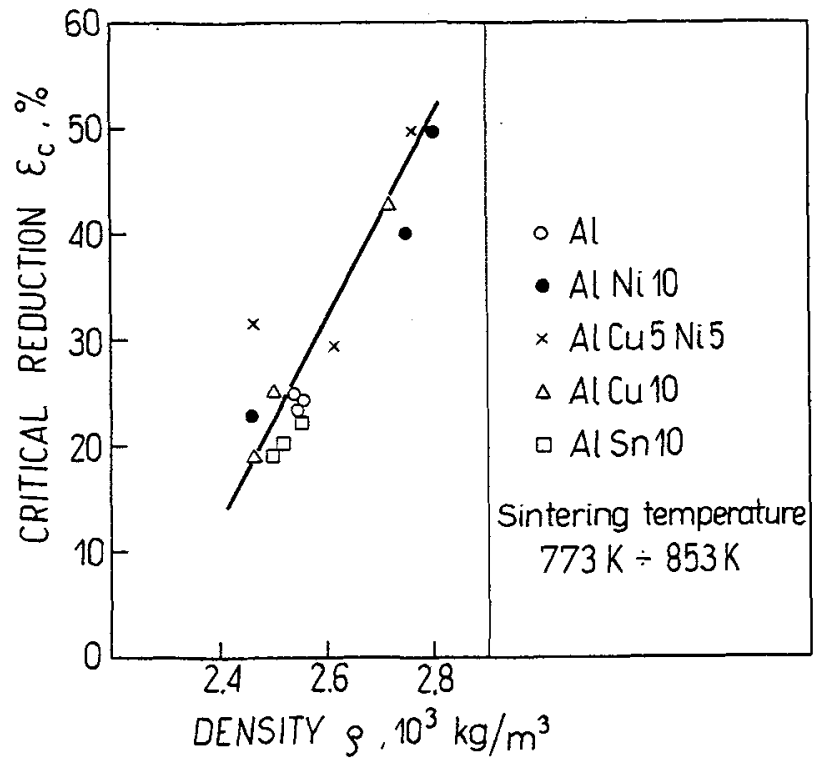

Fig. 2. Critical reduction dependence on sintered density for several Al-based metal powders

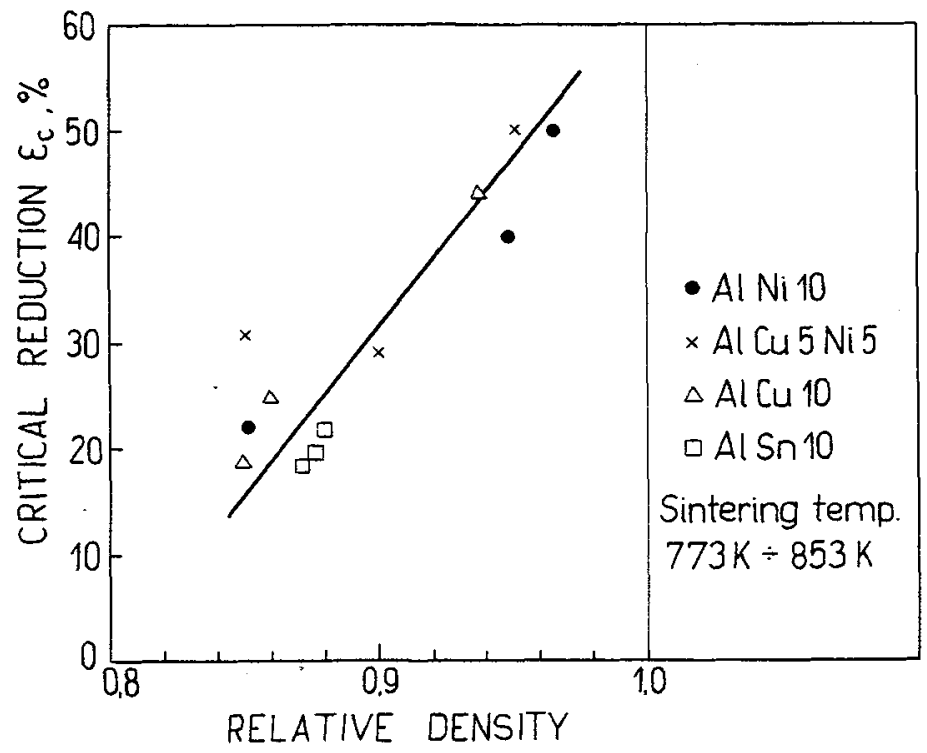

Fig.3. Critical reduction dependence on relative density for several Al-based materials. 


\section{COMMENTS ON THE RESULTS.}

The data shown in figures 2 and 3 indicate that the critical reduction, $\varepsilon$ representing the workability of aluminium-based materials being tested, is proportional to their sintered density. Generally, the workability increases with increasing density. The linear course of the $\varepsilon$, expressed as a function of density or relative density occurs, independentlý of chemical composition of the material. It appears from the experiments that sintering temperature influences density, and in this way the critical reduction also is affected.

Experimentally confirmed linear behaviour of $\varepsilon$ with respect to density may find application in practice. Assuming the lowest critical reduction value resulting in safe leading of deformation process equal to 0.3 , it becomes clear from the graph 3 that the minimum relative density should be of 0.9 at least.

It is known from the literature review that there is no direct works related to the workability-density relationship. Particularly, the question is, whether the observed here dependence is correct for different from Al with additions materials. It has been reported that elongation for sintered copper depends on the relative density; the higher density the higher elongation value [2]. The relative elongation for iron decreases rapidly with increasing porosity, especially within the range of 5-15\% [3]. To be sure, the elongation is not strictly a workability measure, however, there is a certain connection between them and hence the relationship between workability and density is confirmed to some extent.

It is important to note that the observations mentioned above are satisfied for the fcc and partly bcc materials. However, it may not be true for the other metals and alloys, especially for materials of complicated phase structure, and for that containing the considerable amount of brittle phases.

\section{CONCLUSIONS.}

Ability to forming of sintered $P / M$ materials is strongly limited by their density. A linear dependence of workability determined in compression test on sintered density is observed for the Al-based materials above 0.85 of theoretical density.

REFERENCES.

[1] ZASADZINSKI J. and LIBURA W., Proc. of EUROMAT' 91, Cambridge, J.for Materials 1 (1991) 381.

[2] Metals Handbook, v.7., Powder Metallurgy, Am. Soc. for Metals, Ohio (1988).

[3] HEYNES R. , Powder Met. 20 (1977) 17. 